УДК 343.98

\author{
H. I. Клименко
}

\title{
КРИМІНАЛІСТИЧНА МЕТОДИКА: ПОНЯТТЯ, СТРУКТУРА ТА ВДОСКОНАЛЕННЯ
}

Постановка проблеми. Методика розслідування злочинів є структурною частиною науки криміналістики. Вона пов'язана з іншими іiі розділами - загальною теорією криміналістики, криміналістичною технікою і криміналістичною тактикою. У науковій системі криміналістична методика розслідування є загальним розділом, що синтезує наукові положення попередніх розділів. Тому методика розслідування злочинів може розглядатись як особлива частина криміналістики.

Виклад основного матеріалу дослідження. Сутністю методики розслідування окремих видів злочинів є взаємозв'язок двох аспектів - практичного і теоретичного.

Зокрема, це сам процес розслідування злочинів як специфічна діяльність уповноважених законом органів та осіб, що здійснюється на підставі застосування засобів криміналістичної техніки, прийомів слідчої тактики, методів розслідування певних видів злочинів. Це також і розділ науки криміналістики, який містить систему комплексних криміналістичних рекомендацій щодо виявлення, розслідування та профілактики окремих видів злочинів.

Процес розслідування загалом і окремих видів злочинів зокрема включає такі елементи:

- правову діяльність, що здійснюється на підставі процесуальної форми уповноваженими законом органами та особами (слідчим, прокурором);

- пізнавальну діяльність, спрямовану на встановлення обставин події минулого на підставі теорії судових доказів, законів логіки і положень психології;

- організаційну діяльність, спрямовану на забезпечення планомірного розслідування окремих видів злочинів на підставі нормативних приписів, рекомендацій із наукової організації праці;

- профілактичну діяльність, спрямовану на встановлення причин та умов, що сприяли вчиненню злочинів, яка здійснюється на підставі рекомендацій кримінології та криміналістики.

Основою методики є система методів розслідування, що сприяє повному та всебічному розкриттю злочинів, збиранню та об'єктивній оцінці доказів на підставі закону і криміналістичних рекомендацій. 
Основними методами розкриття злочинів є встановлення способу та механізму злочину, його розкриття, встановлення злочинця, виявлення підозрюваної особи, встановлення інших осіб та обставин, криміналістичний аналіз оперативної обстановки.

Серед дисертацій із криміналістики найбільша кількість робіт із методики розслідування окремих видів злочинів (із $544-315$, майже $58 \%$ ) [1].

Різні автори трактують термін «методика» по-різному і дають такі визначення:

- це сукупність взаємозв'язаних способів та прийомів доцільного проведення будь-якої роботи;

- це вчення про методи викладення певної науки, предмета [2].

Аналогічні визначення наведені в інших авторитетних виданнях [3].

М.В Салтевський вважає, що криміналістична методика - це завершальний розділ науки криміналістики, що є системою наукових положень (закономірностей, принципів) і розробленням на їх основі практичних рекомендацій (алгоритмів, програм, які забезпечують оптимальну організацію розслідування і попередження окремих видів злочинів) [4].

Б.В. Щур за результатами аналізу та опитування слідчих МВС, СБУ і прокуратури запропонував структуру криміналістичної методики, яка складається з таких елементів:

1) криміналістична характеристика певного виду групи злочинів;

2) обставини, які підлягають з'ясуванню;

3) попередні дії слідчого до відкриття кримінального провадження;

4) типові слідчі ситуації та система версій початкового етапу розслідування;

5) проміжні завдання і комплекс слідчих дій та оперативно-розшукових заходів початкового етапу розслідування;

6) типові слідчі ситуації та система версій наступного етапу розслідування;

7) проміжні завдання та комплекс слідчих дій і оперативно-розшукових заходів наступного етапу розслідування;

8) заходи усунення протидії розслідуванню злочинів;

9) профілактична діяльність слідчого [5, с. 136-138].

Б.В. Щур також розробив проекти науково-правових актів регламентації процедури державної реєстрації криміналістичних методик.

Криміналістична методика - це своєрідний еталон, що визначає дії слідчого в тих чи інших умовах [7].

Методика розслідування окремих видів злочинів - це частина науки криміналістики, яка має озброїти слідчого науково-методичним комплексом знань і навичок розкриття та розслідування злочинів [8].

B.В. Тіщенко визначив криміналістичну систему наукових положень i рекомендацій, спрямованих на вивчення механізму здійснення злочинів різних категорій та розробку методів і технологій у виявленні, розкритті та розслідуванні [9].

Криміналістична методика - це система визначених елементів, взаємозалежних та взаємозумовлених, розташованих у певному порядку, які становлять структуру методики [10]. 
Вважаємо більш вдалим визначення В.П. Бахіна (1999р.): криміналістична методика - це «заключний розділ науки криміналістики, який $€$ системою наукових положень і розроблених на їх підставі практичних рекомендацій оптимального проведення розслідування злочинів» [11].

Криміналістична методика складається із двох частин:

- загальної (поняття, завдання, зміст та структура);

- окремої (методики розслідування різних видів злочинів).

В.В. Тіщенко вважає, що структура окремих методик розслідування повинна відповідати таким принципам їх побудови:

1) розробка методичних рекомендацій з урахуванням криміналістичних класифікацій злочинів, що дозволить їх дослідити й утворити різного рівня і характеру видову, підвидову, позавидову групи;

2) розробка методики розслідування на підставі криміналістичного аналізу відповідної категорії злочинів та інформаційно-пізнавальної слідчо-криміналістичної характеристики злочинів;

3) визначення кола обставин, що підлягають встановленню у конкретній категорії злочинів;

4) визначення кола і задач розслідування з урахуванням специфіки слідчої діяльності на різних етапах розслідування: початковому, подальшому і завершальному;

5) розробка типових версій і криміналістичних алгоритмів їх перевірки і вирішення тактичних задач на основі інформаційно-ситуаційної оцінки стану розслідування;

6) розгляд і розробка тактичних і технічних прийомів та правил перевірки слідчих дій і тактичних операцій з урахуванням досліджуваної категорії злочинів.

В.В. Тіщенко, як і інші вчені (А.В. Штонін, В.А. Образцов та ін.), надав співвідношення понять «методика розслідування злочинів» і «технологія розслідування» [9].

Завданнями криміналістичної методики (як і загалом науки криміналістики) є сприяння найбільш успішному здійсненню конституційних положень про захист інтересів держави, законних інтересів та прав громадян у вирішенні завдань кримінального судочинства (ст. 2 КПК України), у досягненні мети боротьби з організованою злочинністю (ст.ст. 2, 3 Закону України «Про організаційно-правові основи боротьби з організованою злочинністю)).

На підставі цих завдань у методиці розслідування розрізняють власні завдання з удосконалення наукових рекомендацій щодо підвищення ефективності розкриття злочинів: систематичне узагальнення слідчої, судової та експертної практики; вивчення кримінальної обстановки загалом та в окремих регіонах, стану, структури та динаміки злочинності; аналіз кримінального, кримінально-процесуального, кримінально-виконавчого, адміністративного, цивільно-правового, а також галузевого законодавства, пов'язаного із встановленням юридичної відповідальності за правопорушення у різних сферах діяльності (господарської, фінансової, банківської, податкової, екологічної та ін.). 
Одним із важливих завдань методики розслідування $є$ розробка найбільш ефективних методів і засобів розкриття та розслідування злочинів, побудова їх криміналістичної характеристики, оптимізація процесу розслідування окремих видів злочинів на основі використання даних про типові слідчі ситуації, систему типових версій, комплекси слідчих, організаційних та інших процесуальних дій.

У переліку таких завдань виокремлюється прогнозування змін у структурі злочинності й розробка відповідно до цього нових методик розслідування та вдосконалення тих, що застосовуються. Так, серед актуальних постала розробка методик розкриття і розслідування злочинів проти особи, зокрема вбивств, учинених на замовлення, різних видів економічних злочинів тощо. Вирішення таких завдань відображає одну з найважливіших функцій криміналістики - прогностичну, що особливо важливо в умовах структурних змін і динаміки злочинності.

Особливого значення набуває розробка методик розслідування латентних злочинів, злочинів, що вчиняються організованими групами, до яких належать діяння загальнокримінальні (насильницькі, насильницько-корисливі) та економічні, що вчиняються у сфері виробництва, торгівлі, обслуговування, банківської та іншої економічної діяльності.

Кожна окрема методика розслідування розробляється відповідно до норм Особливої частини KK, що містять опис ознак злочинів певних видів. Норми КПК становлять основу для розробки типових обставин, які підлягають встановленню у процесі доказування у провадженнях про злочини певного виду, і побудови структури окремої методики розслідування.

Критерієм для виокремлення позавидових методик розслідування злочинів може бути не тільки суб'єкт злочину, а й інші фактори, наприклад, рівень організації і професійності злочинності.

Формування позавидових методик здійснюється за рахунок групування різних видів злочинів на основі характерних ознак, що їх об’єднують, і є орієнтиром та способом забезпечення успішності роботи щодо їх розкриття і розслідування.

Особливе значення позавидові методики отримали сьогодні, коли докорінним чином змінилася злочинність, з'явилися нові види злочинів, істотно змінилися способи їх скоєння (використання як засобів скоєння злочинів комп'ютерної техніки, вибухових речовин тощо). Найбільш актуальною є розробка позавидової методики стосовно організованої злочинності.

Сприяти цьому повинна позавидова методика розслідування видів організованої злочинності, яка буде створена на основі узагальнення досвіду боротьби з нею. Причому методика, яка буде відображати не тільки загальні для скоєння злочину параметри (спосіб, слідова картина тощо), а й дані загалом про організовану злочинність, характер злочинної діяльності (ii структуру, форми організації, комплектування «кадрами», систему розвідки і контррозвідки, тактику злочинної діяльності, способи життєзабезпечення тощо). Без створення такої методики результативна й ефективна боротьба з організованою злочинністю не може бути забезпечена. 
Наведені методики розслідування у криміналістичній літературі називаються по-різному: особливі й окремі, комплексні, міжвидові тощо.

Окрема методика становить результат наукового дослідження, узагальнення практики розслідування, систему положень та наукових рекомендацій, які визначають порядок діяльності слідчого під час розслідування окремого виду злочину. Для кожного виду злочинів існують структурні схеми, алгоритми діяльності, які придатні для їх розслідування. Такий алгоритм називають структурою окремої методики.

Так, з'явилися внутрішньовидові методики, наприклад, крадіжок із кафе, квартир і крамниць, викрадання людей (А.Г. Филиппов, Н.А. Бурхаляєв, А.А. Степанов, Я.А. Соколова). Почали формуватися методики відповідно до інших криміналістично значущих підстав (ознак) і більш широких рівнів загальності різних видів злочинів [10].

Варто зауважити, що міжвидові (при цьому підкреслюється їхнє місце в системі) методики було б більш точно назвати позавидовими (що відображає їхню сутність - побудова зовсім за іншим принципом, ніж решта, не відповідно до видових особливостей злочинів, тобто за основним стандартом, а виходячи з інших криміналістично значущих для розслідування ознак, характерних для декількох видів злочинів).

3 урахуванням викладеного види криміналістичних методик схематично можна уявити таким чином.

\section{Криміналістична методика}

\begin{tabular}{|c|c|}
\hline \multicolumn{2}{|c|}{ Основні види методик } \\
\hline $\begin{array}{c}\text { Видові методики } \\
\text { (методика розслідування убивств) }\end{array}$ & $\begin{array}{c}\text { Внутрішньовидові методики } \\
\text { (методика розслідування убивств } \\
\text { на замовлення) }\end{array}$ \\
\hline $\begin{array}{c}\text { Позавидові методики } \\
\text { (методика розслідування злочинів, } \\
\text { скоєних неповнолітніми) }\end{array}$ & $\begin{array}{c}\text { Групові методики } \\
\text { (методика розслідування злочинів, } \\
\text { скоєних службовими особами) }\end{array}$ \\
\hline
\end{tabular}

Сутність криміналістичної методики зводиться до рекомендацій щодо розкриття та розслідування скоєного злочину, коли невідомо, хто його вчинив, і встановлення обставин скоєння, коли спосіб дій винного досить очевидний, але вимагає роз'яснення і з'ясування причин скоєних дій. У найбільш загальному вигляді - це рекомендації щодо виявлення слідів скоєних дій (бездіяльності), їхнього аналізу і правової оцінки.

Для кожного виду злочинів характерні свої специфічні сліди і зумовлені цим засоби і методи їхнього виявлення та «прочитання», тому має місце необхідність розробки окремих методик розслідування певних видів злочинів.

Аналіз специфіки скоєння і розслідування окремих видів злочинів підказав необхідність додаткової деталізації видових методик залежно від особливостей слідчих ситуацій та інших своєрідних обставин здійснення злочинної діяльності. Однак, окрім подрібнення видових методик на специфічні внутрішньовидові, почали висуватися пропозиції про побудову ме- 
тодик розслідування відповідно до інших криміналістично значущих основ (ознак) і більш широкого рівня спорідненості різних видів злочинів.

У зв'язку з цим основою для криміналістичної класифікації злочинів визнавалися:

а) характер первинної інформації, що зумовлює специфіку набору необхідних слідчих дій і їхній зміст;

б) види відображення злочинних дій (в облікових документах, в інших матеріальних та ідеальних слідах);

в) спосіб учинення злочинів, знаряддя і засоби їх скоєння, що використовуються;

г) ступінь приховування і маскування злочину, наявність у винуватого досвіду;

д) особа злочинця і потерпілого [12].

Одночасно із процесом диференціації методик відбувається процес своєрідної інтеграції, коли почали формуватися методики міжвидових груп злочинів, що відображають не видові, а інші особливості вчинення і розслідування об'єднаних видів злочинів. До методик, що отримали досить широке відображення у криміналістичній літературі, можна зарахувати методику розслідування злочинів неповнолітніх, нерозкритих злочинів минулих років, злочинів, скоєних іноземцями і проти них, тощо.

В основу цих методик покладено особливості суб'єкта злочину, вплив фактора часу, специфіки засобів скоєння злочинів тощо. Так, говорячи про злочини неповнолітніх, варто зауважити, що вікові особливості їхнього характеру і поведінки надто своєрідно виявляються як у протиправній діяльності (мотиви і мета скоєння злочинів, вибір і ставлення до предметів посягання, специфіка слідової картини тощо, так і в процесі проведення розслідування (недооцінка того, що відбувається, хибне почуття товариства). Під час розслідування нерозкритих злочинів минулих років основні специфічні моменти пов'язані із заходами щодо маскування слідів злочину й особливостями організації роботи щодо виявлення та усунення недоліків, допущених на початковому етапі розслідування (врахування дії фактора часу, пошук невикористаних можливостей, застосування під час аналізу погляду «збоку» тощо).

В основі кожної такої об'єднуючої (позавидової) методики лежать особливості, шо виходять за межі специфіки конкретного виду злочину та дозволяють виявляти і використовувати в діяльності щодо розкриття і розслідування злочинів додаткові фактори, які визначаються не видом злочину, а ознаками, характерними для групи різних злочинів, і сприяють підвищенню ефективності їх розслідування.

Не можна визнати вдалими спроби формування методик за «гарячими слідами», розслідування «бригадним методом» окремих різновидів злочинів. До них можна віднести злочини проти держави, військові злочини, злочини, скоєні службовими особами, тощо.

Значення позавидових методик зросло особливо в останній час, коли з'явилися нові види злочинів і змінилися способи їх здійснення (із використанням комп'ютерної техніки, вибухових речовин тощо). 
У криміналістичній літературі розрізняють комплексні (А.Ф. Волобуєв), міжвидові (В.В. Радаєв), групові (наприклад, методики розслідування злочинів, що здійснюються посадовими особами) методики $[13 ; 14]$.

Удосконалення криміналістичної методики залежить від розробки ii складових елементів і від більш поглибленого розроблення методик розслідування окремих видів злочинів (екологічних - О.В. Одерій, насильницьких - В.В. Тіщенко, міжнародних - Ю.О. Чорноус, скоєних неповнолітніми - Н.В. Карпінська, групового екстремізму - B.I. Бояров, господарських - Г.К. Прокопанич та ін.).

Ефективний розвиток методики розслідування правопорушень залежить і від використання позитивного зарубіжного досвіду деяких країн (Франції, Англії, країни Європи, США тощо).

Висновки. Розробка вказаних методик розслідування злочинів відображає потреби слідчої практики і є подальшим удосконаленням розвитку криміналістичної методики.

\section{Література}

1. Іщенко А.В. Зміст та форма дисертацій з методики розслідування злочинів / А.В. Іщенко, Д.А. Ляшенко // Криминалистика и судебная экспертиза. - 2015. - Вып. 60. - С. 76-85.

2. Тіщенко В.В. Теоретичні і практичні основи методики розслідування злочинів / В.В. Тіщенко. - Одеса, 2007. - 260 с.

3. Новий тлумачний словник : у 4-х т. - К. : Аконіт, 2001. - Т. 2. - 912 с

4. Салтевський М.В. Криміналістика : [підруч.] / М.В. Салтевський. - Харків : Консул, 2001. $-528 \mathrm{c}$

5. Щур Б.В. Теоретичні основи формування та застосування криміналістичних методик : [монографія] / Б.В. Щур. - Харків : Харків юрид., 2010. - С. 258.

6. Щур Б.В. Функції окремих криміналістичних методик / Б.В. Щур / / Правова доктрина України. - Харків : Право, 2013. - Т. 5: Кримінально-правові науки в Україні: стан, проблеми та шляхи розвитку. - С. 1003-1010.

7. Тіщенко В.В. Теоретичні і практичні основи методики розслідування злочинів /

В. В. Тіщенко. - Одеса, 2007. - 260 с.

8. Криминалистика : [учеб.] / под ред. И.Ф. Герасимова, Л.Я. Дранкина. - М., 2000

9. Тищенко В.В. Криминалистическая методика расследования. Современное состояние и перспективы / В.В. Тищенко ; НУ «Одеська юридична академія». - Одеса, 2010. - Т. 9. C. $170-181$

10. Белкин Р.С. Курс криминалистики / Р.С. Белкин. - М., 2001.

11. Бахин В.П. Криминалистическая характеристика преступлений как элемент расследования / В.Н. Бахин // Вестник криминалистики. - М., 2000. - Вып. 1.

12. Тіщенко В.В. Наукові засади розробки методики розслідування / В.В. Тіщенко // Актуальні проблеми держави і права. - Одеса, 2007. - Вип. 32.

13. Аверьянова Т.В. Понятие криминалистической методики : [учеб.] / Т.В. Аверьянова, Р.С. Белкин, Ю.Г. Корухов, Е.Р. Россинская. - М. : ИНФРА-М, 1999. - 688 с.

14. Образцов В.А. Общие положения криминалистической методики расследования / В.А. Образцов / / Криминалистика : [учеб.] / под ред. В.А. Образцова. - М., 2005.

\section{А н о т а ц і я}

Клименко H. I. Криміналістична методика: поняття, структура та вдосконалення. Стаття.

Розглянуто поняття криміналістичної методики як структурної особливої частини науки криміналістики, як взаємозв'язок теоретичних та практичних аспектів, як єдність двох частин - загальної та окремої; виокремлено ії завдання, найбільш ефективні методи і за- 
соби розкриття та розслідування злочинів; розкрито структурну схему (алгоритм діяльності) розслідування; наведено принципи криміналістичної методики, співвідношення понять «методика розслідування злочинів» і «технологія розслідування», основи криміналістичної класифікації злочинів; класифіковано окремі види методики з відображенням їх особливостей; систематизовано умови вдосконалення криміналістичної методики.

Ключові слова: криміналістична методика, особлива частина, поняття, структура, методи, видові (позавидові) методики, вдосконалення.

\section{Ан н о т а ци я}

Клименко $H$. И. Криминалистическая методика: понятие, структура и совершенствование. - Статья.

Рассмотрено понятие криминалистической методики как структурной особенной части науки криминалистики, как взаимосвязь теоретических и практических аспектов, как единство двух частей - общей и отдельной; выделены ее задачи, наиболее эффективные методы и средства раскрытия и расследования преступлений; раскрыта структурная схема (алгоритм деятельности), расследования; приведены принципы криминалистической методики, соотношение понятий «методика расследования преступлений» и «технологии расследования», основы криминалистической классификации преступлений; классифицированы отдельные видовые и вневидовые методики с отражением их особенностей; систематизированы условия совершенствования криминалистической методики.

Ключевые слова: криминалистическая методика, особая часть, понятие, структура, методы, видовые (вневидовые) методики, совершенствование.

\section{S u m m a r y}

Klymenko N. I. Forensic methodology: concept, structure and improvement. - Article.

The concept of criminalistic methodology as a structural special part of the science of criminalistics is considered as a correlation of theoretical and practical aspects, as the unity of two parts, general and separate, its tasks are singled out, the most effective methods and means for disclosing and investigating crimes are the structural scheme (algorithm of activity) The principles of the criminalistics methodology, the correlation of the concepts "investigation methodology of crimes" and "investigation technologies" are given: the basis of criminalistic classification of crimes, separate specific and non-specific methods for reflecting their features are classified, and the conditions for improving the forensic methodology are systematized.

Key words: forensic methodology, special part, concept, structure, methods, specific (non-specific) techniques, improvement. 